\title{
Love, Friendship, and Teenagers Social Conflict in Novel Things About Him by Nara Lahmusi
}

\author{
Zulfadhli $^{1}$, M I Nasution ${ }^{2}$ \\ \{zulfadli@fbs.unp.ac.id ${ }^{1}$ ismail_n@fbs.unp.ac.id²
}

\author{
${ }^{1,2}$ Faculty of Languages and Arts, Universitas Negeri Padang, Padang, Indonesia
}

\begin{abstract}
This article contains a discussion of teenagers issues presented in novel Things about Him by Nara Lahmusi. The purpose of this study is to: 1) describe the problem of teenagers love in the novel Things about Him by Nara Lahmsui; 2) describe the issue of friendship in the novel Things about Him by Nara Lahmsui; 3) describe teenagers social conflicts in Nara Lahmusi's novel Things About Him. This research will be carried out in several stages. The first stage of this research is the literature study by collecting references that have relevance to the research problem from various sources. The second stage of this research is data collection with the following steps: 1) reading the novel that has been used as an object of material intensively; 2) identify aspects related to the research problem; and 3) record the results of identification. The third stage is data analysis, and the last stage is to reveal the results of the analysis and discussion. Based on the analysis and discussion, it can be concluded that 1) the love problem expressed in the novel Things about Him by Nara Lahmusi is the love of school-age youth with all its problems. The problem of love is presented in a simple style typical of teenagers. The love problem that is described in this novel as a representation of teenage life, especially urban teenage life as a form of popularity. This can be seen in the author's description and narration displayed through his characters. 2) friendship in social groups will form the dynamics of relationships that tend to remain. This is a strategy in maintaining the group. Conflict will arise if one part of the group resigns or moves to another group. The pattern of teen friendship expressed in this novel is a representation of popularity. 3) teenagers social conflicts contained in this novel include: family conflicts (parents), social conflicts (friends).
\end{abstract}

Keywords: Love, friendship, teenagers, social conflict

\section{Introduction}

In the latest development of Indonesian literature, one interesting phenomenon to be studied and researched is the emergence of popular novel genres. The emergence of popular novels has given a new color to the development of modern Indonesian literature. The presence of popular novels cannot be underestimated, due to the fact that popular literature has placed itself in an important position in the development of Indonesian literature. Popular literature has become a part of the study, analysis, criticism, and study of Indonesian literature.

As a literary work, popular novels are able to express and reflect various social phenomena that occur in society. The life of the people featured in popular novels is a reflection of the social reality of the community. Thus, popular novels depict a reality, a culture because literature is a product of culture. Swingewood (1972: 43) argues that literary works are social reflections, so that the birth of a literary work is inseparable from the socio-cultural aspects of society. Lotman (in Faruk, 2005: 47) revealed that literature is a discourse that models an unlimited universe in a limited imaginary universe.

Popular literature is often treated as inferior and has no aesthetic value. Ariel Heryanto cited popular literature as an example of literature that grew up in the "bottom", "margins, or "outside" literary forums. Popular literature is considered not worth enough to be noticed or valued (Faruk, 2005: 99). Thus, the position of popular literature is constructed lower than "inaugurated" literature. The concept of separating Indonesian literary works is seen as a practice of hegemony. The hegemony was formed by the formation of the assumption that official literature had the highest place and the satra outside it was positioned at the lower strata. (Faruk, 2005: 99). 
On the other hand, popular culture is a study that is not easy to learn because it involves dimensions that are quite sensitive in society. It is in this context that studying popular literature as one of the products of popular culture is important. Popular literature is useful to explain the cultural phenomena of the creator and audience (Adi, 2011: 11).

Thus, popular literary works are a cultural product. As a cultural product, popular literature is a part of people's lives. Its existence is even more complex, in line with the increasing complexity of various socio-cultural phenomena that occur in society.

In the last decade, popular novels in Indonesia have increasingly presented various and varied forms with the publication of chick-lit and teen-type novels. The presence of chick lit and teenlit became one of the literary phenomena which gave birth to many reactions from various readers. The phenomenon of the presence of these novels is one marker of the revival of popular literature in the world of Indonesian literature. This implies that the emergence of popular novels adds to the treasury of the development of the latest Indonesian literature.

The problem of love, friendship, and adolescent social conflict is one of the problems that is often expressed in popular novels. One popular teenlit novel that expresses the problem of love, friendship, and teenage social conflict is Nara Lahmusi's novel Things about Him.

In accordance with the research problem, this research used the theory of sociological literature. The sociology of literature as suggested by Levin (in Elizabeth and Tom Burns, 1973: 31). According to Levin "literature is not only the effect of social causes but also the cause of social effects." Levin's statement provides a direction that the study of literary sociology can be towards the relationship of the mutual influence between sociology and literature.

In literary sociology, first of all literary works can be social documents and can be a picture or mirror of society at an age. In this view, literature is a direct description of various aspects of social structure, family relations, and class conflict. The researcher is tasked to connect the imaginary experiences of the author and the historical climate gained by the author. The novel represents the world, this concept must be held because of the enormous influence in the study of literary sociology (Swingewood, 1972: 13).

In the relationship between sociology and literature, Swingewood (1972: 15) presents a positive outlook. He did not side with the view that considers literature as merely a side material. He reminded that in conducting a sociological analysis of literary works, critics must be careful in interpreting the slogan "literature is a mirror of society" because literary works were created by authors using a certain set of equipment. The great author does not merely describe the social world rawly, but he has an urgent task, namely to play the characters in a fictional situation to express and find value and meaning in the social world.

Meanwhile, Teeuw (1983: 11) explained that literature was not born in a cultural vacuum. Therefore, literature can be considered as a socio-cultural record or document. The same thing was also stated by Junus (1986: 3) that literary works are socio-cultural documents that express the sociocultural reality of a society at a certain time. Literary works are not seen as a whole, but rather from socio-cultural elements in them as elements that are free from the unity of the work.

Sociology of literature covers many aspects. Swingewood (1972: 13) explains several perspectives relating to the sociology of literature. The first of the most popular is research that views literary works as social documents in which they are a reflection of the situation at the time the work was created. Second is the study of literary sociology that emphasizes the social situation of the author as the person who produces a literary work. The position of the author in the community and historical background greatly influences the development of literature because when the text was created it was much influenced by the historical background of an era. The third perspective in the study of literary sociology is how researchers trace public acceptance of a literary work or community reception of a literary work.

\section{Methods}

The research method is determined and selected according to the characteristics of the object of study. In this connection, literature as a science has its own scientific characteristics. ChamamahSoeratno (2001: 12-13) explains that literary research has the truth of its own method although it is still scientific. The application of scientific methods in literary research also needs to consider the nature of literature that shows universal but at the same time special or unique phenomena.

The data in this study are words, phrases, or sentences contained in the novel that relate to the problem under study. The data source of this research is novel Things about Him by Nara Lahmusi. 
This research is a qualitative research with descriptive method. According to Bogdan and Taylor (in Moleong, 2002: 3) qualitative methods are research procedures that produce descriptive data in the form of written or oral words from people and observable behavior.

This research will be carried out in several stages. The first stage of this research is the literature study by collecting references that have relevance to the research problem from various sources. The second stage of this research is data collection with the following steps: 1) reading the novel that has been made as an object of material intensively; 2) identify aspects related to the research problem; and 3) record the results of identification. The third stage is data analysis, and the last stage is to reveal the results of the analysis in the form of a research report.

\section{Result and Discussion}

\subsection{Love in Novel Things about Him by Nara Lahmusi}

The issue of love is a problem that is always present in popular Indonesian novels. The problem of love expressed explicitly illustrated through the characters presented. Interest in the opposite sex usually starts from an accidental encounter, or through a third party. Relationship sometimes also begins with a dispute and displeasure with a partner who ultimately leads to love. As illustrated in the following quote.

"Dion...waktu itu gue memang sayang banget sama lo. Gue menganggap lo lebih dari sekedar sahabat. Tapi, gue nggak bisa ngungkapin dan malah menyimpannya selama itu. Tapi, itu dulu, "Aku masih terisak. "Maafin gue ya, Dion. Maaf kalau gue udah nggak sanggup lagi sama lo. Karena hati gue sudah untuk cowok lain. (Lahmusi, 2018: 224)

The quote describes the character Cinta who falls in love with Jason. In fact, Jason is a man who was hated by Love before. However, Jason continues to try to get love Cinta in various ways. Giving serious attention and always caring about Love is a step for Jason to approach Cinta. Over time the character Cinta has a fondness for Jason. In fact, the first love of Love is Dion. Depictions of love like this are characteristic in teenagers.

Love for Jason is also illustrated in the following quote.

"Tapi, itu semua terhenti sejak gue bertemu Jason. Dia yang mengembalikan hidup gue, Dion. Dia yang perlahan, mengikis rasa sedih gue yang terasa tertumpuk karena kehilangan lo. Untuk itu sekarang gue ingin ngucapin selamat tinggal. Hati gue sekarang sudah memilih Jason buat dia tinggal di dalamnya. (Lahmusi, 2018: 224)

Changes in feelings in a relatively short time is a natural psychological thing for adolescents. Teenagers have characters that are still unstable, tend to change, and think instantly and have a dominant emotional aspect.

\subsection{Friendship in Novel Things about Him By Nara Lahmusi}

As a form of popularity, adolescents are usually joined in certain groups which they call gang. These groups usually consist of several people who have the same character, dimensions, vision. They in the group become formed a friendship. This arena is a place to meet, gather, play, and also as a means to solve various problems faced by group members. Within groups, there are usually conflicts and conflicts between members as a form of self-expression. In its existence as a group, competition will usually also occur with other groups (gangs). Competition between gang groups is common in teenagers' lives. Competition is one of the directions raised by adolescents as a form of culture and as a venue for defending groups from the threat of other groups.

Competition among adolescent groups is not only in love, but there are also other competitions, such as in the form of competitions (basketball, photography, cheerleaders) and in the form of seeking the attention of others. 
In the novel Things about Him, also illustrated how the relationship of friendship and competition between adolescent groups. As performed by the characters Love, Jason, Dion, and Ramon. This is seen in the following quote.

"Gue nggak punya siapa-siapa lagi Ta selain Claudia. Cuma dia yang selalu ada buat gue. Tapi sekarang dia udah pergi.

"Lo kan masih punya gue, Mon. Inget, gue temen lo. Gue bakal selalu jadi temen lo."

"Seharusnya gue benci sama lo sejak awal Ta. Karena ketulusan lo nggak bisa ngelakuin hal jahat itu.

“Jadi, kalau bukan Jason, siapa yang mukulin lo waktu itu?" tanya Cinta pelan.

Tangis Ramon terhenti, berubah jadi kebencian. Tangannya mengepal hebat. Dalam sorot matanya ada luka yang dalamnya tak sanggup kubayangkan (Lahmusi, 2018: 185).

The quote illustrates that in adolescent social groups, conflicts often occur, conflicts within groups, as well as with other groups. This pattern of friendship is an identity of popular culture that makes teenagers the central figure.

\section{Teenager Social Conflict in Novel Things about Him by Nara Lahmusi}

Psychologically, adolescence is a transitional age between childhood and adulthood. At this age, synonymous with various problems and conflicts. Even small things can become big problems. Adolescent social conflicts in this novel are seen in individual conflicts, conflicts in social groups (gangs), and conflicts in the family.

In the novel Things about Him, the character Cinta as the main character has a family conflict with parents (mama). The treatment of his mother who is always busy with his personal affairs, regardless of family, father, and children (love). Her mother's behavior had an influence on Cinta's personality. Love becomes emotional, irritable, easily offended, often broken hearted and disappointed. The relationship that is not harmonious between his parents gives psychological impact on the personality of Love. The love conflict with his mother is seen in the following quote.

Mama selalu bilang terang-terangan menikah dengan Papa tanpa cinta. Seperti cerita klasik karya Marah Rusli, mereka dulu dijodohkan. Mereka memberiku nama Cinta agar aku bisa menyatukan mereka, menjadi perekat hubungan mereka. Namun, sepertinya aku gagal. Keributan mereka yang entah untuk kesekian kalinya, baru saja reda tepat pukul sepuluh malam. Kalau tidak ada pertengkaran lagi, artinya papa sibuk di laboratorium untuk membuat starter nata, sementara Mama sibuk membaca buku atau menulis novel di laptop (Lahmusi, 2018: 29).

The relationship that is not harmonious between her parents has an impact on the psychological personality of Love. Environmental influences affect a person's personality, especially family environment. The attitude of non-love Love towards her mother is illustrated in the following quote.

"Kenapa dia nggak mau menemuiku, Pa?" Tanyaku semakin sedih.

"Papa yang melarangnya, Papa takut kamu belum bisa memaafkan mama,

"kata Papa. Kata-kata itu seperti jarum-jarum halus yang kini ditusukkan ke hatiku. "Tapi semua itu juga karena Mama. Dulu dia egois."

"Nah, kan Papa benar, kamu masih dendam."

Teenager social conflict can originate from oneself, groups and from families. All of these things give psychological influence on the development of adolescent personality. 


\section{Conclusion}

The presence of popular novels has given a new color to the development of modern Indonesian literature, as well as a representation of modern society. The issues expressed therein are also increasingly complex and universal. These issues include issues of adolescent love, friendship, social conflict as a reflection of urban society. As revealed in the novel Things about Him by Nara Lahmusi.

\section{References}

[1] Laurenson, D., and A. Swingewood.: The sociology of literature. Paladin, London (1972)

[2] Faruk: Pengantar sosiologi sastra: Dari strukturalisme genetik sampai post-modernisme. Pustaka Pelajar, Yogyakarta (2005)

[3] Adi, I R.: Fiksi populer: Teori dan metode kajian. Pustaka Pelajar, Yogyakarta (2011)

[4] Elizabeth and T. Burns.: Sociology of literature and drama. Pinguin Books Inc. Australia, (1973)

[5] Teeuw, A.: Membaca dan menilai sastra. Gramedia, Jakarta (1983)

[6] Junus, U.: Sosiologi sastra; persoalan teori dan metode. Dewan Bahasa dan Pustaka Kementerian Pelajaran Malaysia, Malaysia (1986)

[7] Chamamah-Soeratno, S.: "Penelitian Sastra: Tinjauan tentang Teori dan Metode Sebuah Pengantar" dalam Metodologi Penelitian Sastra. Hanindita Graha Widya, Yogyakarta (2001)

[8] Moleong, L. J.: Metodologi penelitian kualitatif. PT Remaja Rosdakarya. Bandung (2002)

[9] Lahmusi, N.: Things about him, Gramedia Pustaka Utama, Jakarta (2018) 